\title{
Morphological and Functional Changes of the Small Intestine in Growth-Stunted Broilers
}

\author{
L. LENHARDT $^{1}, \breve{S}$. MOZES̆ ${ }^{2}$ \\ ${ }^{1}$ Department of Pathology, University of Veterinary Medicine, Košice, Slovakia \\ ${ }^{2}$ Institute of Animal Physiology, Slovak Academy of Sciences, Košice, Slovakia
}

Received October 24, 2002

Accepted September 22, 2003

\begin{abstract}
Lenhardt, L, Š. Mozeš: Morphological and Functional Changes of the Small Intestine in Growth-Stunted Broilers. Acta Vet. Brno 2003, 72: 353-358.

The development of morphology and function of the small intestine was related to body weight changes in commercially bred broilers with free access to food. At days 16 and 36 of age the broilers were divided into four groups (12 broilers in each) with normal growth and with retarded growth and morphometric parameters (villous height and crypt depth) and the activity of brush-border-bound alkaline phosphatase (AP) in the duodenum and jejunum were determined. The results revealed significant villous atrophy and crypt hypertrophy $(p<0.001)$ as well as marked decrease of densitometrically determined AP activity $(p<0.001)$ in broilers with retarded growth as compared to normal growing control chickens during both periods under study. Our results indicate that these morphological and functional changes in the small intestine (despite free access to food) may result in impairing its absorptive capacity for normal body weight development. They may also be the underlying cause for the persistence of a decreased body weight in broilers in which the stunting syndrome had developed.
\end{abstract}

Broiler, stunted growth, duodenum, jejunum, morphometry, brush border, enterocyte, alkaline phosphatase

The stunting syndrome is a frequent disease of post-hatch broiler and turkey chickens manifested in early periods by uneven growth, depression in food intake, impaired digestion and utilization of nutrients as well as by delayed feathering. Possible causes of this syndrome ultimately resulting in the development of typical "helicopter chicks" with stunted body weight might be pathogen-related enteric disorders. Evidence has been provided that the stunting syndrome might be experimentally induced by oral administration of an inoculum prepared from the intestine of broilers and turkeys in which the disease had been diagnosed (Angel et al. 1990ab; Shapiro and Nir 1995a; Shapiro et al. 1998; Songserm et al. 2002). While in healthy chicks increase of daily food intake is linear with rapid growth during the two weeks after hatch (Murakami et al. 1993; Uni et al. 1995), in chicks affected by stunting syndrome decrease of food intake, their utilization and weight loss has been inversely related to the age of the animals. The most prominent effect of the inoculum was observed on days 1-3, a moderate influence was seen between days 3 to day 7, while at day 14 no effect was found (Shapiro and Nir 1995a).

Many previous data on development of the stunting syndrome in broilers and turkeys have revealed a different timing of incidence and intensity of disorders during initial and final digestion of food. While administration of the inoculum obtained from infected animals resulted in decreased pancreatic enzyme levels after day 14 (Shapiro and Nir 1995a; Shapiro et al. 1998), and digestive enzyme supplementation of their diet from hatching to day 14 did not alter the course of the stunting syndrome till day 28 (Shapiro and Nir 1995b). In contrast, villous atrophy (Angel et al.1990b; Song serm et al. 2002) and crypt hypertrophy (Perry et al. 1991) as well as decreased mucosal disaccharidase activity were present from day 3 and 7 in the small intestine of the stunted birds (Angel et

Address for correspondence:

MVDr Štefan Mž̌s, PhD.

Ústav fyziológie hospodárskych zvierat, SAV

Košice
Phone: +421556783183

Fax: +421557 287842

http://www.vfu.cz/acta-vet/actavet.htm 
al. 1990; Shapiro et al. 1997, 1998). Despite early appearance of both morphological and enzymatic changes in the small intestine their participation, mainly that of functional disturbances in spreading of the disease, are not fully understood. Moreover, some research carried out to investigate the stunting syndrome in chicks revealed the persistence of depressed growth and food utilization until day 21 (Shapiro et al. 1998), while the initially decreased activity of jejunal maltase and saccharase on day 7 gradually increased thereafter, and on days 14 and 21 reached the values found in non-infected chicks (Sh a piro et al. 1997, 1998).

Among the intestinal enzymes, alkaline phosphatase (AP) is a representative brush border enzyme functionally involved in the active uptake of nutrients (Takase and Goda 1990; Bernard et al. 1992; Kaur et al. 1996) and it is considered to be a marker of enterocyte maturation (Weiser 1973; Henning 1981). Their activity reflects the actual nutritional situation decreasing during fasting and after food restriction (Majumd ar and Panda 1989; Palo et al. 1995). These results suggest a close relationship between the feeding status and AP activity and also indicate that rapid functional changes in the small intestine are elicited by a quantitative nutritional experience. At present, however, little information is available about intestinal AP activity in broilers whose growth retardation developed despite their immediate access to food after hatching. Such fundamental data for the AP activity would be useful for better understanding of the contribution of the intestinal function to the development of the stunting syndrome. In the present study, AP activity in the brush-border of duodenal and jejunal enterocytes and the morphometric parameters of the small intestine were therefore examined in 16- and 35-day-old broilers raised under ad libitum feeding conditions but displaying either normal weight gains or stunted body growth.

\section{Materials and Methods}

A total of 48 broilers (Hybro) from the same hatch housed after hatching with free access to food (commercial diet: HYD 01 and from day 21 HYD 02) were used. On the basis of manifestation of delayed growth and feathering the chicks were divided into two groups (12 broilers in each): 1 . normally growing broilers (controls), 2 . growthretarded birds; they were killed on days 16 and 35 by cervical dislocation.

For morphometrical analysis small intestinal tissues (duodenum and jejunum) were fixed in $10 \%$ neutral buffered formalin solution, embedded into paraffin, sectioned $(5 \mu \mathrm{m})$ and stained with hematoxylin eosin. The mean values of villus height (measured from the tip to the crypt junction) and crypt depth (depth of invagination between adjacent villi) were calculated from at least 10 vertically oriented structures.

For histochemical analysis the samples obtained from the small intestine were immediately frozen and stored at $-20^{\circ} \mathrm{C}$. A segment of the frozen tissue was cut at $7 \mu \mathrm{m}$ in the cryostat at $-25^{\circ} \mathrm{C}$ and the tissue slices were transported to glass slides and air-dried. From each tissue segment six sections were cut for enzyme assay. Demonstration of alkaline phosphatase activity was performed using a modified simultaneous azo-coupling method according to Lojda et al. (1979). The incubation medium contained naphthol AS-BI phosphate (Sigma, Deisenhofen, Germany), Fast blue BB (Aldrich, Germany), N.N-dimethylformamide (solvent for naphthol AS-BI phosphate) and veronal acetate buffer ( $\mathrm{pH} 9.2$ ). Incubation was performed at $37^{\circ} \mathrm{C}$ for $10 \mathrm{~min}$, using a substrate concentration of $2.0 \mathrm{mM}$ and a $\mathrm{pH}$ of 8.9. Enzyme activity was cytophotometrically analysed with a Vickers M85a microdensitometer. The measurements were carried out by means of an $\times 40$ objective, an effective scanning area of $28.3 \mu \mathrm{m}^{2}$ and a scanning spot of $0.5 \mu \mathrm{m}$. The integrated absorbance was measured at a wavelength of 480 $\mathrm{nm}$. The mask was set over at least 30 brush border areas along the villus length (from the cryptal parts to the tip) in the duodenal and jejunal sections. AP activity was calculated as the absorbance values recorded by the instrument in $\mathrm{min} / \mathrm{mm}^{-3}$ brush border $\pm \mathrm{SEM}$.

Statistical evaluation of the results was carried out by one-way analysis of variance (ANOVA). Significance of the differences between the control and experimental animals was determined by using Tukey's test.

\section{Results}

On day 16 after hatching the stunted broilers weighed about $60 \%$ less than normally growing controls and these differences in body weight remained significant until day 35 (Table 1). 
Table 1

Body weight and alkaline phosphatase (AP) activity in the duodenum and jejunum of control and growth stunted broiler chicks

\begin{tabular}{|lcccc|}
\hline & \multicolumn{2}{c}{ Day 16 } & \multicolumn{2}{c|}{ Day 35 } \\
& Controls & Stunted & Controls & Stunted \\
\hline $\begin{array}{l}\text { Body weight }(\mathrm{g}) \\
\text { AP activity }\end{array}$ & $411 \pm 4$ & $151 \pm 4^{*}$ & $948 \pm 4$ & $373 \pm 5^{*}$ \\
Duodenum & $8.5 \pm 0.2$ & $3.7 \pm 0.1^{*}$ & $9.5 \pm 0.2$ & $4.1 \pm 0.1^{*}$ \\
Jejunum & $8.0 \pm 0.1$ & $2.7 \pm 0.1^{*}$ & $6.9 \pm 0.1$ & $3.2 \pm 0.1^{*}$ \\
\hline
\end{tabular}

Data are means \pm S.E.M. of 12 chicks in each group. AP activity is given as the integrated absorbance in $\mathrm{min} / \mu \mathrm{m}^{3}$ brush border of enterocytes at a wavelength of $480 \mathrm{~nm}$. Significantly different from the controls: ${ }^{*} p<0.001$ (ANOVA with Tukey's test).

Changes in morphology of the small intestine in growth-retarded and normally growing chicks observed on days 16 and 35 are shown in Figs 1 and 2, and also in Figs 3 and 4 (Plate I). During both periods, villus height and crypt depth were consistently higher in duodenum than in jejunum and with age these intestinal parameters increased in both groups of broilers. On the other hand, a significant decrease of villus height $(p<0.001)$ occurred in the duodenum and jejunum (about $70 \%$ and $60 \%$ on days 16 and day 35, respectively); a significant increase $(p<0.001)$ of crypt depth in these segments (about 50 and $14 \%$, on day 16 and day 35, respectively) was found in the growth-retarded groups when compared to the controls (Fig. 1 and 2).

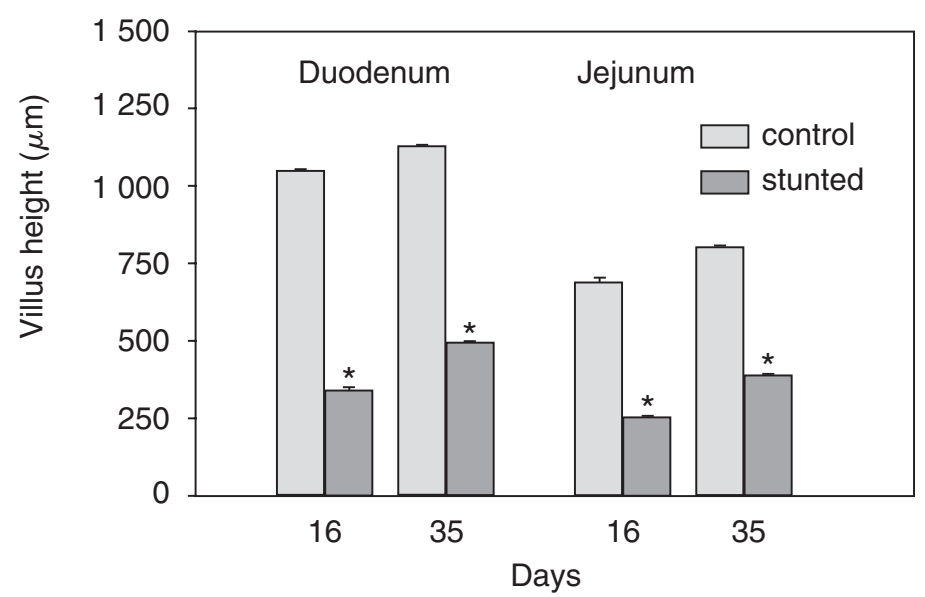

Fig. 1. Villus height $(\mu \mathrm{m})$ in the duodenum and jejunum from control and growth stunted broiler chicks. Values are means \pm S.E.M. from 12 birds. $* p<0.001$ significantly different from the controls.

Brush-border bound alkaline phosphatase (AP) activity in the duodenum and jejunum of 16and 35-day-old broilers is shown in Table 1. The mean AP activity along the intestinal villus corresponded with the changes of body weight i.e. the growth stunted chicks displayed a significantly decreased enzyme activity as compared to the intact controls (Plate II, Figs 5 and 6). The differences of enzyme activity between these groups represent about $60 \%$ in the duodenum and jejunum on day 16 and a similar tendency has also been confirmed on day 35 (Table 1). 


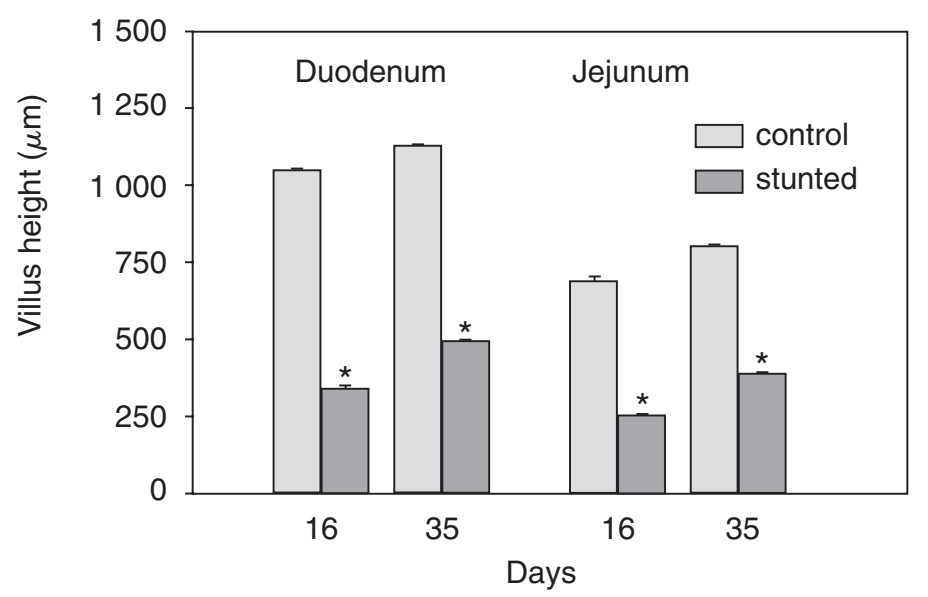

Fig. 2. Crypt depth $(\mu \mathrm{m})$ in the duodenum and jejunum from control and growth stunted broiler chicks. Values are means \pm S.E.M. from 12 birds. $* p<0.001$ significantly different from the controls.

\section{Discussion}

In general, in broiler chicks the onset of exogenous food intake after hatching is associated with rapid growth of the small intestine, progressive changes in the digestive and absorptive function of the gastrointestinal tract characterized by enhanced secretion of pancreatic enzymes into the duodenum (Baranyiová 1972; Uni et al. 1995a), an increased uptake capacity of the proximal small intestine for glucose and amino acids (Noy and Sklan 1996), as well as increased absorption of dietary lipids (Murakami et al. 1992). At that time rapid structural and functional changes occurred in the intestinal mucosa i.e. increase of the apical surface area in epithelial cells (Ferrer et al.1995), increase of enterocyte density and villus height particularly over the first 7-10 post-hatch days (Uni et al. 1995ab; Iji et al. 2001a) and also increase of the intestinal brush-border bound enzyme activity i.g. alkaline phosphatase activity which peaked at 2 to 4 days posthatch and decreased thereafter (Uni et al. 1998; Iji et al. 2001b).

The distinct morphological changes in small intestine observed in the present experiment on day 16 and 35 of growth retarded broiler chicks are in agreement with studies in which longterm villus atrophy and crypt hypertrophy of the intestinal mucosa was demonstrated when the poults were placed after hatching on litter on which the malabsorption syndrome and growth stunting had previously developed (Perry et al. 1991). Furthermore, our results revealed a similar pattern of enzyme changes throughout the investigated periods i.e. significantly decreased duodenal and jejunal AP activity in broilers with retarded growth as compared to the normally growing controls. The exact mechanism inducing these permanent morphological and functional changes observed when feed was freely available, has not been fully elucidated. It has been well established that a crucial requirement for normal growth and development of the small intestine is also the presence and amount of food in the alimentary tract. Fasting for 1 to 5 days after hatch may depress subsequent development of the intestinal mucosa i.e. it decreased the villous diameter, the number of crypts per villus in the duodenum and jejunum (Baranyiová 1972; Baranyiová and Holman 1976; Uni et al. 1998; Geyra et al. 2001) and led to long-lasting body weight retardation (Halevy et al. 2000). Similarly, early nutrient restriction of broiler chickens (from day 7 to 14 of age) results in 
a reduced weight of the gastrointestinal organs and a decreased jejunum cell number (Palo et al. 1995a). Moreover, such a decrease in energy intake led to different adaptational changes in the jejunal enzymes; it lowered the AP activity at day 14 and increased maltase and sucrase levels at day 21 of age (Palo et al. 1995b). Although the same phenomenon of decreased AP activity and morphological retardation in the small intestine has been observed both in birds after limited food or energy intake and in broilers in which the stunting syndrome was diagnosed, some differences between these models do exist. First, it was found that undernutrition results in only transient changes in the small intestine i.e. after refeeding or switching to normal energy intake the above mentioned enzymatic and morphological disturbances gradually disappeared and returned to normal values at later periods (Palo et al. 1995ab; Uni et al. 1998). Second, an opposite effect of early insufficient nutrition has been observed on overall efficiency of feed conversion: in food-restricted broilers it elicited increased utilization of the ingested nutrients whereas in stunting syndrome-affected broilers it resulted in a long-term depression of feed utilization (Palo et al. 1995b; Shapiro and Nir 1995a; Shapiro et al. 1998). Finally, as compared to the controls, growth-stunted broilers, as stated in the present study, exhibited a significantly decreased AP activity even when they were exposed to entirely similar feeding conditions after hatching which indicates that the stunting syndrome infection per se may differently affect the development of the intestinal epithelium.

The present results extend our knowledge on intestinal morphology and brush-borderbound AP development in broilers. It can therefore be speculated that early affliction in small intestine morphology and function until infection is really shown may also be critical and result in impaired absorption of nutrients for normal body weight development. However, with regard to presented data, further detailed research is be needed to clarify whether the decreased efficiency of nutrient absorption, the sustained decrease of AP activity or both may be the underlying cause for the persistence of decreased body weight in broilers in which the stunting syndrome was established.

\section{Morfologické a funkčné zmeny v tenkom čreve brojlerových kurčiat zaostávajúcich $\mathrm{v}$ raste}

U brojlerových kurčiat komerčne chovaných za podmienok volného prístupu ku krmivu bol sledovaný morfologický a funkčný vývoj tenkého čreva vo vztahu k zmenám telovej hmotnosti. Na 16. a 36. deň veku, broilerove kurčatá boli rozdelené do dvoch skupín (12 broilerov v každej vekovej skupine): a) s normálnym rastom, b) so spomaleným rastom. U týchto vekových skupín boli sledované morfometrické parametre (výška klkov a híbka krýpt) a aktivita alkalickej fosfatázy (AF) v mikrovilóznej zone enterocytov duodena a jejuna. Výsledky v oboch sledovaných periódach poukázali na signifikantnú atrofiu klkov a hypertrofiu krýpt $(p<0.001)$ ako i na výrazné zníženie densitometricky stanovenej aktivity AF $(p<0.001)$ u broilerových kurčiat zaostávajúcich $\mathrm{v}$ raste $\mathrm{v}$ porovnaní so skupinou kurčiat normálne rastúcich. Výsledky naznačujú, že zaznamenané morfologické a funkčné zmeny $\mathrm{v}$ tenkom čreve (napriek volnému prístupu ku krmivu) môžu rozhodujúcou mierou ovplyvnit a) nutričné požiadavky pre normálny telesný vývoj, b) byt významným faktorom prispievajúcim k udržaniu zníženej telovej hmotnosti u kurčiat so syndrómom zaostávania v rate.

Acknowledgement

This work was supported by the grant 2/2039 of the Slovak Academy of Sciences.

References

ANGEL, CR, SELL, JL, TRAMPEL, DW 1990a: Stunting syndrome in turkeys. Development of an experimental model. Avian Dis 34: 447-453 
ANGEL, CR, SELL, JL, TRAMPEL, DW 1990b: Stunting syndrome in turkeys: physical and physiological changes. Poult Sci 69: 1931-1942

BARANYIOVÁ, E 1972: Influence of deutectomy, food intake and fasting on the digestive tract dimensions in chickens after hatching. Acta Vet Brno 41: 373-384

BARANYIOVÁ, E, HOLMAN, J 1976: Morphological changes in the intestinal wall in fed and fasted chickens in the first week after hatching. Acta Vet Brno 45: 151-158

BERNARD, A, CASELLI, C, BLOND, JP, CARLIER, H 1992: Dietary fatty acid composition, age and rat jejunal microvillus enzyme activity. Comp Biochem Physiol 101: 607-612

FERRER, R, PLANAS, JM, MORETO, M 1995: Cell apical surface area in enterocytes from chicken small and large intestine during development. Poult Sci 74: 1995-2002

GEYRA, A, UNI, Z, SKLAN, D 2001: The effect of fasting at different ages on growth and tissue dynamics in the small intestine of the young chicks. Br J Nutr 86: 536-61

HALEVY, O, GEYRA, A, BARAK, M, UNI, Z, SKLAN, D 2000: Early posthatch starvation decreases sattelite cell proliferation and skeletal muscle growth in chickens. J Nutr 130: 858-864

HENNING, SJ 1981: Postnatal development: Coordination of feeding, digestion, and metabolism. Am J Physiol 241: G199-G214

IJI, PA, SAKI, A, TIVEY, DR 2001a: Body and intestinal growth of broiler chicks on a commercial starter diet. 1. Intestinal weight and mucosal development. Br Poult Sci 42: 505-513

IJI, PA, SAKI, A, TIVEY, DR 2001b: Body and intestinal growth of broiler chicks on a commercial starter diet. 2. Development and characteristics of intestinal enzymes. Br Poult Sci 42: 514-522

KAUR, M, KAUR, J, OJHA, S, MAHMOOD, A 1996: Dietary fat effects on brush border membrane composition and enzyme activities in rat intestine. Ann Nutr Metab 40: 269-276

LOJDA, Z, GROSSRAU, R, SCHIBLER, TH 1979: Enzyme Histochemistry. Springer-Verlag, Berlin, 59 p.

MAJUMDAR, S, PANDA, JN 1989: The activities of phosphatases and aminotransferases in the epithelium of the small intestine and caecum of White Rock cockerels during starvation. J Vet Med A 36: 348-353

MURAKAMI, H, AKIBA, Y, HORIGUCHI, M 1992: Growth and utilization of nutrients in newly-hatched chick with or without removal of residual yolk. Growth Dev Aging 56: 75-84

NOY, Y, SKLAN, D 1996: Uptake capacity in vitro for glucose and methionine and in situ for oleic acid in the proximal small intestine of posthatch chicks. Poult Sci 75: 998-1002

PALO, PE, SELL, JL, PIQUER, FJ, SOTO-SALANOVA, MF, VILASECA, L 1995a: Effect of early nutrient restriction on broiler chickens. 1. Performance and development of the gastrointestinal tract. Poult Sci 74: 88101

PALO, PE, SELL, JL, PIQUER, FJ, VILASECA, L, SOTO-SALANOVA, MF 1995b: Effect of early nutrient restriction on broiler chickens. 2. Performance and Digestive enzyme activities. Poult Sci 74: 1470-1483

PERRY, RW, ROWLAND, GN, GLISSON, JR 1991: Poult malabsorption syndrome. I. Malabsorption in poult enteritis. Avian Dis 35: 685-693

SHAPIRO, F, NIR, I 1995a: Stunting syndrome in broilers: physical, physiological, and behavioral aspects. Poult Sci 74: 33-44

SHAPIRO, F, NIR, I 1995b: Stunting syndrome in broilers: effect of age and exogenous amylase and protease on performance, development of the digestive tract, digestive enzyme activity and apparent digestibility. Poult Sci 74: 2019-2028

SHAPIRO, F, MAHAGNA, M, NIR, I 1997: Stunting syndrome in broilers: effect of glucose or maltose supplementation on digestive organs, intestinal disaccharidases, and some blood metabolites. Poult Sci 76: 369380

SHAPIRO, F, NIR, I, HELLER, D 1998: Stunting syndrome in broilers: Effect of stunting syndrome inoculum obtained from stunting sydrome affected broilers, on Broilers, Leghorns and Turkey Poults. Poult Sci 77: 230236

SONGSERM, T, ZEKARIAS, B, VAN ROOZELAAR, DJ, KOK, RS, POL, J.M, PIJPERS, AA, TER HUURNE, AA 2002: Experimental reproduction of malabsorption syndrome with different combinations of reovirus, Escherichia coli, and treated homogenates obtained from broilers. Avian Dis 46: 87-94

UNI, Z, NOY, Y, SKLAN, D 1995a : Posthatch changes in morphology and function of the small intestines in heavy- and light-strain chicks. Poult Sci 74: 1622-1629

UNI, Z, NOY, Y, SKLAN, D 1995b : Development of the small intestine in heavy and light strain chicks before and after hatching. Br Poult Sci 36: 63-71

UNI, Z, GANOT, S, SKLAN, D 1998: Posthatch development of mucosal function in the broiler small intestine. Poult Sci 77: $75-82$

UNI, Z, NOY, Y, SKLAN, D 1999: Posthatch development of small intestinal function inthe poult. Poult Sci 78: 215-222

TAKASE, S, GODA, T 1990: Effects of medium-chain triglycerides on brush border membrane-bound enzyme activity in rat small intestine. J Nutr 120: $969-976$

WEISER, MM 1973: Intestinal epithelial cell surface membrane glycoprotein synthesis. I. An indicator of cellular differentiation. J Biol Chem 248: 2536-2541 
Plate I

Lenhardt L., Mozeš. Š.: Morphological... pp. 353-358

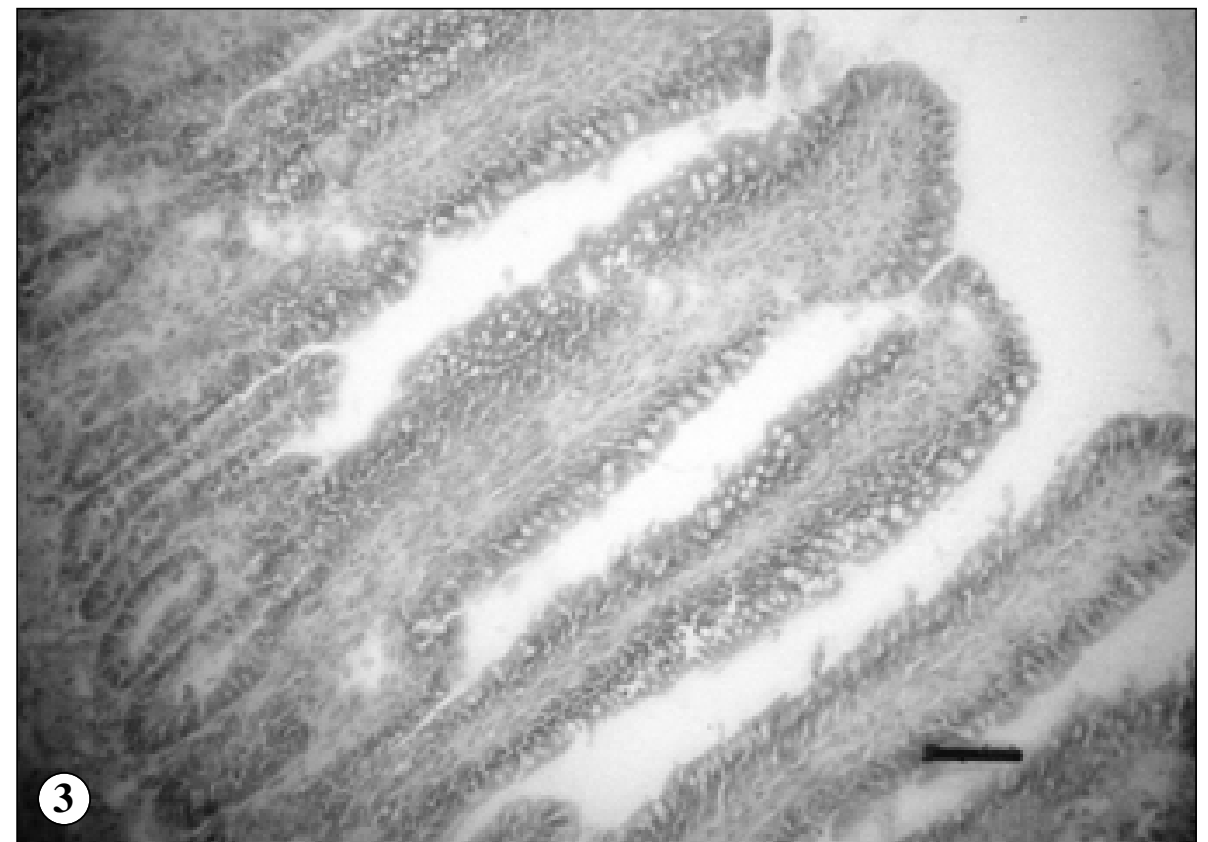

Fig. 3. Light micrograph of chick jejunum intestinal villi from a 35-day-old control broiler chick. Sections were stained with Hematoxylin-eosin. Bar $=40 \mu \mathrm{m}$.

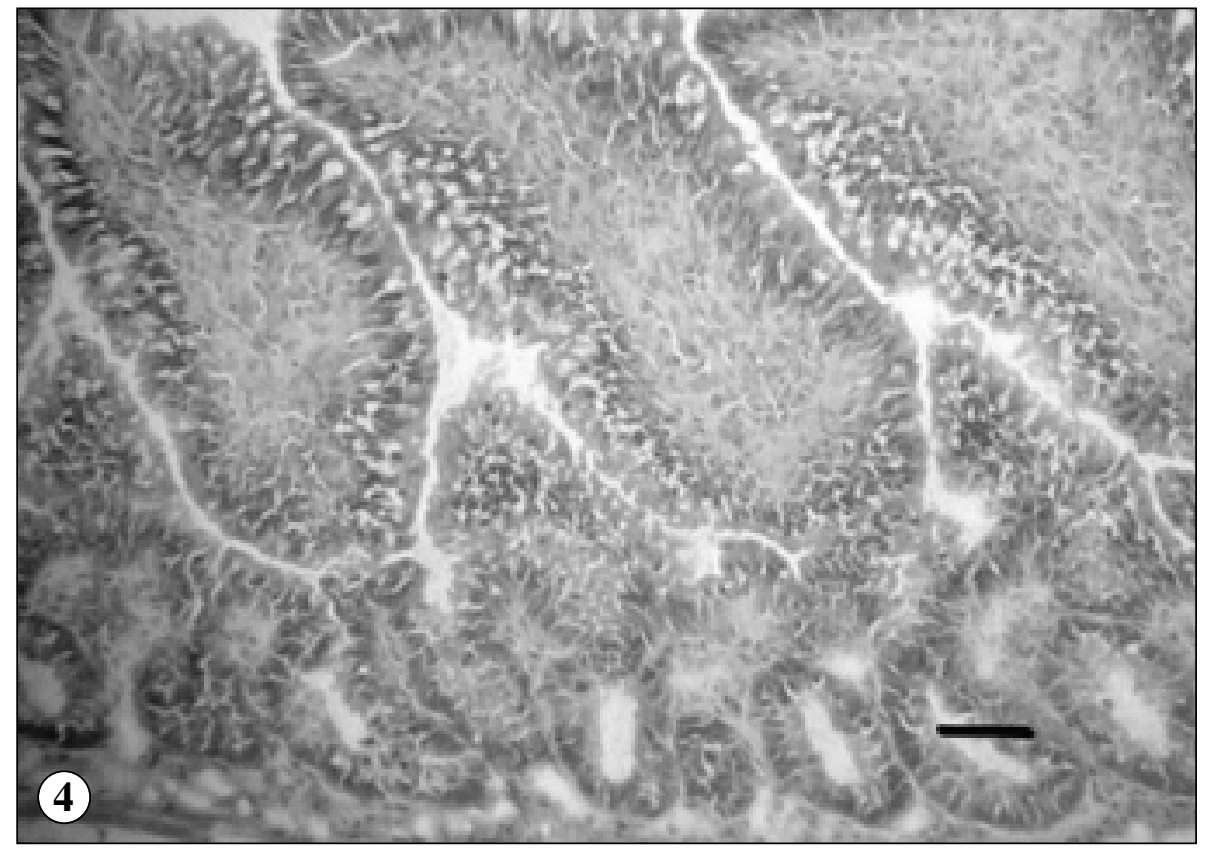

Fig. 4. Light micrograph of chick jejunum intestinal villi from a 35-day-old growth-stunted broiler chick. Sections were stained with Hematoxylin-eosin. Bar $=40 \mu \mathrm{m}$. 


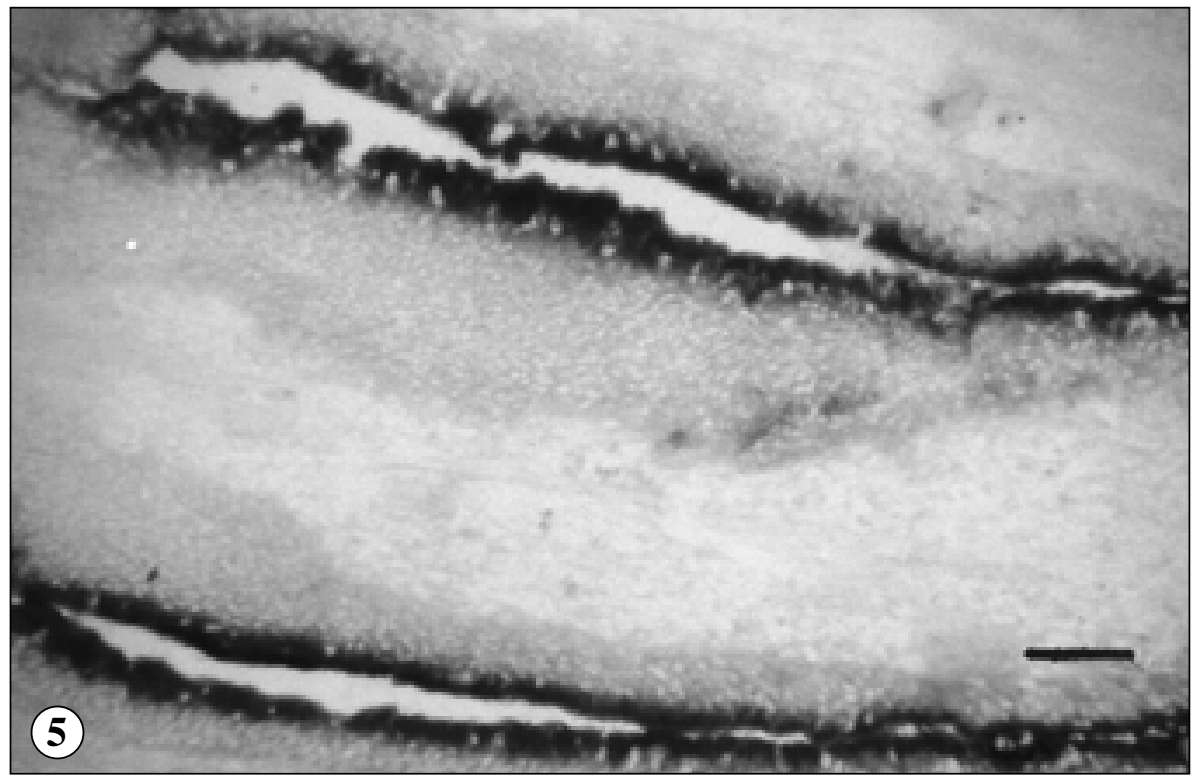

Fig. 5. Alkaline phosphatase activity along the villus axis in a 35-day-old control broiler chick. The incubation medium contained naphthol AS-BI phosphate and Fast blue BB. Incubation was performed at $37^{\circ} \mathrm{C}$ for $10 \mathrm{~min}$, using a substrate concentration of $2.0 \mathrm{mM}$ and a $\mathrm{pH}$ of 8.9 . The final reaction product is localized in brush border of duodenal epithelial cells. Bar $=30 \mu \mathrm{m}$.

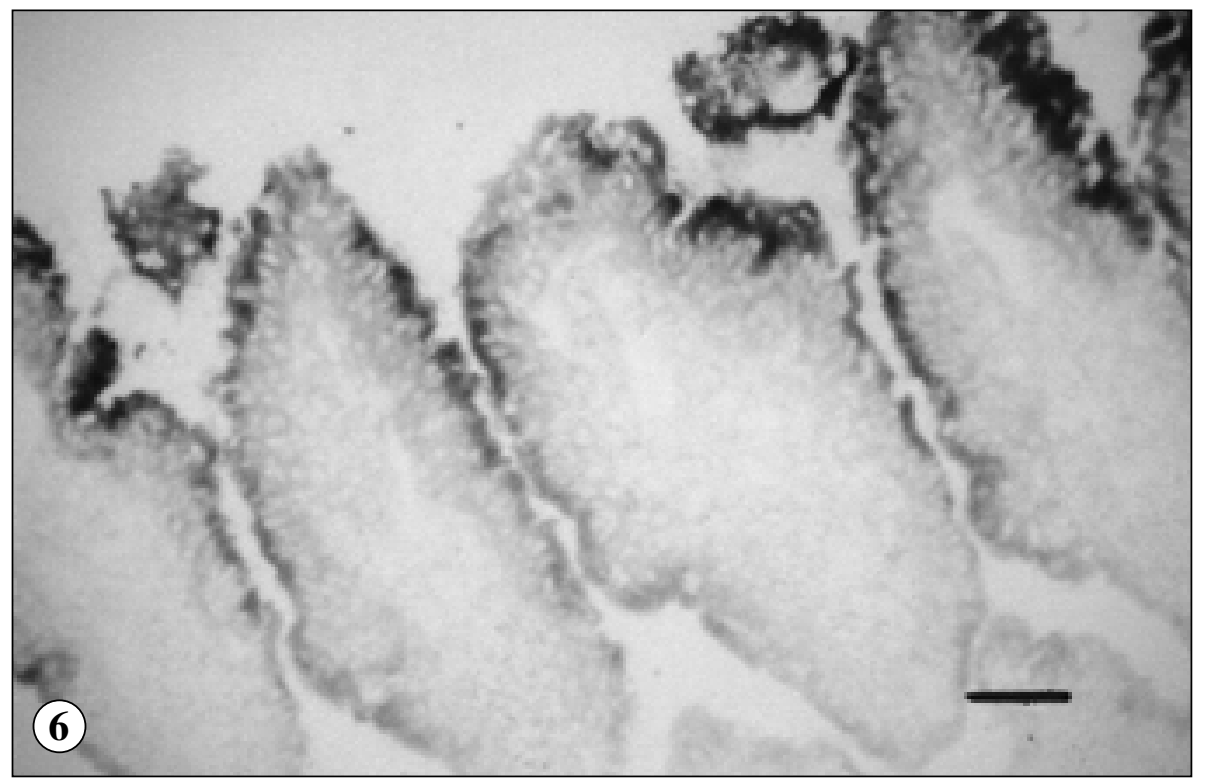

Fig. 6. Alkaline phosphatase activity along the villus axis in a 35-day-old growth stunted broiler chick. The incubation medium contained naphthol AS-BI phosphate and Fast blue BB. Incubation was performed at $37^{\circ} \mathrm{C}$ for $10 \mathrm{~min}$, using a substrate concentration of $2.0 \mathrm{mM}$ and a $\mathrm{pH}$ of 8.9 . The final reaction product is localized in brush border of duodenal epithelial cells. Bar $=30 \mu \mathrm{m}$. 